\title{
Primary Source Analysis of Malleus Maleficarum
}

\author{
Danli Wei ${ }^{1}$
}

\author{
${ }^{1}$ Chongqing Nankai Secondary School, Chongqing 40003, China, WDL228098@outlook.com
}

\begin{abstract}
This work conducts a systematic analysis of Malleus Maleficarum to understand medieval witchcraft. The analysis was divided into four parts. The first part is the introduction about the author Heinrich Kramer's and Jacob Sprenger's background, intention, and how their identities as members of Dominican Orders affected their writing. The second part provides the context within which the work was written and discussed how the geographic and social factors affected the content of the work. The third part explains several key terms to understand the text. The fourth part narrows the focus to the chapter discussing the relation between the god and witchcraft, displaying the position of religion and witchcraft in contemporary people's mind and the connection between the two.
\end{abstract}

Keywords: Malleus Maleficarum, Witchcraft, Free Will

\section{INTRODUCTION}

Malleus Maleficarum was published in the German city of Speyer in 1486. By then, the witch trial had became rampant. However, the understanding of sorcery and the form of trail were quite distinct in different region. Therefore, the author of Malleus Maleficarum Jacobus Sprenger and Henricus Ubstitoris decided to write this comprehensive introduction of witchcraft to standardly witch trials. The work was not only crucial for modern historians to understand the sorcery itself then, but also can give us a glimpse on the other respect of Europe society as that time, like Christian religion, the cornerstone of medieval society. To better utilize Malleus Maleficarum as a lens to understand contemporary religion and its function, in the work we attempt to resolve some basic paradox between the nature of God and the existence of witchcraft in medical period.

It was believed to be written by Jacobus Sprenger and Henricus Ubstitoris, who come up with this idea of writing this comprehensive introduction on the sorcery after controversial inquisition in Innsbruck.

\section{ABOUT THE AUTHOR}

Malleus Maleficarum is generally recognized to be written by 2 authors, Jacobus Sprenger and Henricus Institoris. To better understand the text, the life of the two authors should be analyzed first.

Jacobus Sprenger was born in about 1437 and joined the Dominican Order in about 1453. The Dominican
Order is an organization established in the 13th century that aimed to combat heresy. Because the target of the Dominican Order is to eliminate heresy work opposing the orthodox church teaching, the necessity for them to study theology leads to a tight connection with the local university. In the case of Sprenger, he was associated with the university in Cologne, and he eventually became the professor of theology who served as an administrator in both the theological faculty and the university as a whole. The focal point of Sprenger's work was on pushing inner reform of the church and the spread of the practice of reciting the Rosary. Sprenger was appointed as an inquisitor in the Rhineland in 1481, but there was not much evidence of his active participation in the witch trial, and he was not a person have a strong inclination on writing, either.

Henricus Institoris, also a member of the Dominican Order and was appointed to inquisitor in a number of German dioceses, was deeply involved in the sale of indulgences, and in particular, he undertook a number of tasks connected with the defence of papal privileges and the enforcement of orthodoxy rather than conduct mainly the academic works as Sprenger [1]. Institoris was a person with a strong personality that finally led to his decision to write Malleus Maleficarum after a conflict during which trial with the Innsbruck bishop [2].

The trial in Innsbruck took place on the morning of October 29th, 1485, with Institoris attending as the inquisitor. The accusation was on an aggressive and independent woman, Helena Scheuberin, who had publicly cursed the Institoris and referred to him as an evil 
man in league with the devil. Holding the belief that the sorcery work is inevitably connected with sexual immorality, Institoris kept asking questions on the sexual experience of Saumer in an offensive manner, making others in the interrogation uncomfortable. Then the lawyer Johann Merwai whose presence was sanctioned by the bishops' representatives issued the challenge on the validity of the trial and the rightness of the procedure. After the confrontation, the suspect was released under the objection of Institoris. The conflict reflected the distinct idea about the definition and the nature of the witch in the 15 th century. After being humiliated in this event, Institoris made a decision to write a detailed and comprehensive defence of his beliefs [3].

Sprenger and Institoris's experience as members of the Dominican Order had an impact on the reasoning style of the work. First, the members of the Dominican Order, though took the same vows of poverty as monks, lived among the laity to root out the heresy and enforce orthodoxy, which gives ample chance to receive the case of common people's witches. Combined with Institoris' interest in missions among the laity than the academic works, most examples used in Malleus Maleficarum are about those unpleasant and unpopular individuals held responsible for damaging crops, souring milk, and causing illness out of petty malice, in whose trials rumour, hearsay, and legend played an important part. Moreover, Dominican training generally asked the authors to accept the testimony at its face value. Most of the time in the work, the phrase" reliable witnesses" is used to authenticate the content, often resulting one-sided notion of witchcraft without the opinion of authors with different experience, like many other traditional works [4].

\section{ABOUT THE CONTEXT}

The Malleus Maleficarum was published in 1486, written by two German writers in the Holy Roman Empire [5].

Basically, the early period of witchcraft, from 1300 to 1500 , can be divided into 4 stages: 1300 to 1330,1330 to 1375,1375 to 1435 and 1435 to 1500 . For the first three stages, most trials pertained to the political plots. However, the connection between diabolism and sorceries were established in the third stage, and in stage 4 this idea of witchcraft would have been accepted on the vast land of German, Switzerland and France [6].

The diabolic witches are believed to originate in Western Switzerland in the first half of the 15th century, then spread through western Europe for the rest of the century. Early in about 1430s, the persecution of Waldensians in the Fribourg Vaudoisie trials can be seen as the first example of the fusion between heresy and witchcraft. The witch trials conducted by the inquisitors of Lausanne from 1438 were examples of the early noticeable witch trials, which were involved by secular judges just like the later trials. Then came the Council of Basel that played a prominent role in the dissemination of witchcraft. Between the year 1431 to 1437, Duke Amadeus VIII of Savoy, whom the council elected as anti-Pope Felix V by the counsel. However, Pope Eugene IV, who successfully defended his claim to the papacy against the election of Felix V, lambasted Savoy as a land brimming with heretics: Waudenses - the term at that time could mean either Waldensians or witches. Right after the political struggle, the doctrine on the witches held by the inquisitors began to develop through the whole Western Europe, as manifested by trials in Heidelberg in 1446 and again in 1475, in Metz in 1488, in Arras and vicinity from 1459 to 1462 , and in the bishopric of Trier in the early 1490s. Except for the conflict between the pope and Counsel of Basel, the connection formed between the Little Ice Age and Witch trial also contributed to its popularity, since the dramatic climate change seemed can only be explained by the supernatural power in the 15th century [7].

At this very time, mythology and its function varied from place to place. For instance, it was women who were more likely to conduct witchcraft according to the pervasive myth of Strega in Italy. Thus, the subjects of almost all witchcraft in Perugia were women, while the trial targets were more diverse in German and other areas [8].

The information above may explain the time and place The Malleus Maleficarum was published _ It can be seen that The Malleus Maleficarum was written near the hearth of the burgeoning witchcraft, the South part of the Holy Roma Empire, at the very time the idea of the witch trial spread across German. Also, the diverse interpretation of witchcraft and the operation of the trial in the 15th century may encourage the author to use this book to standardize the notion of witchcraft and the procedure of trials.

\section{SUMMARY}

In this part, the authors primarily clarify the role of God in the sorceries by arguing that God actually gives permission to the sorceries and explaining why.

First, the authors display six counterarguments stating that it is not heretic to say God does not permit the sorceries to happen. The first two items talk about the nature of God that is neither powerless to forbid witchcraft nor hostile to permit it to happen even HE is capable to prevent it. And considering sorceries are basically evil affairs, it will not be insulting to the divine and just God by rejecting his connection with witchcrafts. Argument 3 to 5 are established on the grounds of the nature of the witchcrafts themselves. Those evils are "base things", thus being not the concerns to God, or some of them are the necessity of nature which are acting free of the providence. Argument 6 challenges the idea about 
the permission given by God in terms of logic. While witchcrafts, should be exerted on those sinful persons, the ones that suffer the most from these evil magics are actually innocent people, which can be seen as contradictory.

Then, the authors provide the general response to the arguments above. The central ideas are God permit the evil things (the witchcraft here) to be done for the universal good, but it does not mean that HE wants them to happen, but HE has to let them happen. The more complete version of the authors' idea comes in the following response part. First, he uses some ink to tackle the controversy on the scale of the providence from God and the justness of his permission to the totality of evil. Decisively the authors suggest that God offers providence to everything HE creates, meaning everything on the earth, without any exception. Then, using the benefits to humans from killing animals in nature as an example, the authors claim that if those evil things are eradicated from the world, there will be a lack of good things. In other words, God benefits the world by permitting the occurrence of sorceries, so it was justifiable.

To further justify the conduct of God, the questions on the ability to sin are discussed. For the creatures, they are imperfect that can not obtain the capability not to sin; and for God, it is just not to give angles and humans such ability. The keyword here is "free will" which is bestowed to human beings with the providence given by God. Such freedom allows humans to determine to withdraw or not withdraw on their own. Given that the ability to sin is the ability to withdraw from God, which is guaranteed by the providence, will contradict the principle of free will to forbid the sorceries and other evil conduct to be performed. Meanwhile, the ability not to sin seen through the Confirmation of Grace can not be taken as the nature of humans but the incidental effects of the nature of God. Thus, it could be concluded that God has the ability no to sin as the result of his own nature, while the creatures he creates possess the free will due to his goodness, but not the ability not to sin as it will be inconsistent with the principle of the free will.

Then, the detailed description of how the first angle fell in the next part serves as the manifestation of the reasoning above. Holding the attempt to spread the blessedness and goodness by itself, the desire to do so causes its decadence. By showing that the most divine thing created by God is given permission to the very sin, the author confirms the idea that the sin conducted by humans, the sorcery here, is permitted by God without any questions.

For the final part, the authors refute the argument appearing in the first part based on the discussion above one by one. First, he eliminated the doubt based on the nature of God by emphasizing the ability of God to actually benefit the world by permitting the evil things, which reveals his goodness and perfection suggested by the sceptics. Then the author shows the common people should not study the base things due to the difficulty in understanding and the risk of being misled, while God knows them all well. By claiming that God's providence actually reaches to everything he creates, and even the natural works, which have been already proved in the previous part, the authors assure that it is heretic to say the God does not give permission to the sorcery due to its nature. And for the last counterargument, the authors answer by swaying the discussion to the intention of the Devils. Devils want to harm God to the greatest extent by tempting those originally innocent people instead of those who have already been loaded with sins. This explains why the victim of the sorceries were the most innocent people.

\section{TERMINOLOGY}

1. Providence: It refers to the protective care from God or from nature as a spiritual power.

2. Almighty: It refers to having complete power; omnipotent

3. Elect: It refers to those who have been, or will be, elected, or chosen by God for a purpose: to

become the first fruits of salvation.

4. Grace: It refers to the free and unmerited favour of God, as manifested in the salvation of sinners

and the bestowal of blessings.

5. Confirmation: It refers to the rite at which a baptized person, especially one baptized as an

infant, affirms Christian belief and is admitted to be the full member of the church.

6. Base thing: It refers to the evil behaviour conducted by the people like the sorcery works.

\section{INTERPRETATIONS}

From page 213 to 227 , the central role of free will in Christianity is illustrated, especially in the part concerning the ability to sin.

In 68A, the author reasons that:" This was brought about by free will. Just as it is characteristic of free will to act or refrain from acting, it is characteristic of it to withdraw and not withdraw from its cause, and because the ability to sin is the ability to withdraw from God as a result of the freedom

of choice, therefore neither man nor angel could receive the ability not to sin, nor could the possession of freedom of choice and the ability not to sin be shared with him by God at the same time," to prove that the ability to not to sin can not exist among the creatures. The author sets the assumption that every creature possesses free will like the 
premise to have the following discussion on the ability to sin, which means that free will was considered as the foundation in Christianity during the period that everyone admitted the existence of a free will and used it to prove other theological ideas. In this paragraph, the author also clarifies the notion of sin: withdrawal from God. This gives the readers an idea of how people understood sin itself and its relation to God. A person has sin when he loses faith in God, like those doing sorceries, which manifests the dominating position of Christianity and God during the period as the general concept of evil could be explained simply as the disbelief to God.

Such belief on the free will can also be seen in the 69D: "Since man and angel were created and left in a state of free will for the same purpose, namely that of not receiving the reward of blessedness without merit, then, just as the angel was not preserved from his fall so that for the beauty of the universe the power to sin should be made manifest from the one and the power of the Grace of Confirmation from the other, this had to be the case with man's being preserved." The author first illustrates the justness for God to permit the first angel to fall in this paragraph, then states that in the same way and for the same reason God permits the humans to fall, for the benefits of the universe. The derivation from the angel to humans here totally based on the existence of free will and the sameness of the nature of free will for all creatures. These all show the free will was a core part of the theological reasoning at that period that the authors use it directly as a principle to derive the further conclusion.

Even though from the counterarguments to the authors, the influence of free will can also be seen. In 70D:" The Apostle removed the concern of God from oxen in order to show that because a reasoning creature has control over his own actions through free will, as has been stated, so that something should be imputed to him as guilt or merit and that a penalty or a reward should be given to him accordingly, God exercises a specific providence about this." Here the doubt casted to the author was based on the firm belief that men and other reasoning creatures have free will, the evidence of the specific providence from God. Even the utilization of free will lead to different conclusions, the free will always take a central role in the theological discussion.

As the idea of free will was so important, it contributed to the theory of sorceries and witch trial a lot. In fact, free will was the keyword to explain why God permits sorcery to happen. In 68A referred to above, the ability to $\sin$ is the ability to withdraw from God. Since freedom bestowed by God guaranteed the ability to sin, no creatures can avoid sins, otherwise, it would contradict the doctrine of free will. The occurrences of sorcery, as a typical expression of the loss of faith in God, were sins emerging spontaneously with the incontrovertible belief in free will. Thus the reference to the idea of free will can illustrate the reason God permits the sorceries.

\section{CONCLUSION}

The work first probes into the context of Malleus Maleficarum to find that the authors' experience and social conditions then might influence contents of the work hugely, reminding historians to consider more when interpret the work. After a though analysis, the work first explains it was the idea of free that will resolves the paradox between the existence of sorcery and the nature of god. Then it jumps out from the research of witchcraft to show the indispensable position of religion in the mind of medieval people. Based on this interpretation of the context and content of Malleus Maleficarum, we may first be able to trace the origins and developments of the some consistent theological issues, and have a better understanding of the importance of religion in human history and some religions problems of present society.

\section{REFERENCES}

[1] Christopher S. Mackay, The Hammer of Witches (New York: Cambridge University Press, 2009), 2-3

[2] Janine Larmon Peterson, "Intro and Excerpt Commentary: Henricus Institoris and Jacobus Sprenger: Malleus maleficarum.” (2010): 844-859. https://www.academia.edu/509484/

Intro_and_Excerpt_Commentary_Henricus_Institor is_and_Jacobus_Sprenger_Malleus_maleficaru m

[3] Hans Peter Broedel, The Malleus Maleficarum and the construction of witchcraft(New York:Manchester University Press, 2003), 1-3

[4] Christopher S. Mackay, The Hammer of Witches (New York: Cambridge University Press, 2009), 5

[5] Christopher S. Mackay, The Hammer of Witches (New York: Cambridge University Press, 2009),1

[6] Richard Kieckhefer, European Witch Craft: Their Foundations in Popular and Learned Culture, 1300 - 1500 (Berkley: University of California Press, 1976), 11-26

[7] Laura Stokes,"Prelude: Early Witch-Hunting in Germany and Switzerland." Magic, Ritual, and Witchcraft, Volume 4, Number 1 (summer 2009): 54-61

[8] Richard Kieckhefer, "Mythologies of Witchcraft in the Fifteenth Century." Magic, Ritual, and Witchcraft, Volume 1, Number 1 (summer 2009), 79-108 